\title{
Linus: The Rise and Fall of Lyric Genres
}

\author{
Andrew Ford*
}

Schemes for classifying works of art according to genre flourish outside the academy_in bookstores, on music-streaming services, on Netflix; yet in literary studies genre criticism has been facing increasing resistance since the 1980 os when Frederic Jameson pronounced it "thoroughly discredited by modern literary theory and practice." Suspicion hangs over the word in academic criticism, where it often seems that no sooner is a genre mentioned than its integrity as a concept is undermined and any normative authority it might have had is dismissed. One senses at times a Nietzschean disdain for genres as cobwebs spun out by desiccated pedants which supermen-poets brush through without a thought. Such attitudes have, to be sure, some grounds: it would be naïve now to regard genres as pure and timeless essences rather than hybrid, politically conditioned and contingent groupings of works that are always evolving and always changing their "laws." Demystifications of genre can, however, overshadow its other, productive side, the possibilities it offers to sharpen and enrich a message and to provide orientation for an audience hearing a song for the first time. The fact that the authority and perpetuation of genres depend on poets and audiences at least as much as on scholars is not always acknowledged, nor is the reality that genres are omnipresent and inescapable: we greet no song without a frame.

The status of genre is no less suspect in the study of those Greeks who laid out many of the basic lines and much of the terminology used in Europeanderived criticism. In the article on "genre" for the current Oxford Classical Dictionary, for example, Glenn Most and Gian-Biagio Conte aim for a balanced presentation but find little positive to say about ancient genres. They note that genre can be useful for poets and critics if it be regarded as "a system of literary projection inscribed within the texts, serving to communicate certain expectations to readers and to guide their understanding." Yet they find ancient

* Thanks to the participants and organizers of the conference at Berkeley for stimulating the thoughts in this essay, which I had the opportunity to present to the Classics Department of New York University in December 2015. Particular thanks are also due to Stephen Menn and to the editors of this volume for searching and productive criticism.

1 Jameson 1981: 91, a much-cited tag. 
discussions of specific genres "for the most part unsatisfactory": these are characterized as "one-sidedly formal" and "more interested in classifying existing works than in understanding the mechanisms of literary production and reception." The systems the ancients built up, they write, are more relevant to "the needs of the school and the library" than to the interpreter, for they not only ignore some important genres such as the novel but "bungle" others-and here they name lyric poetry.

Indeed, out of all classical genres, lyric seems to be the most suspect, both as a coherent general category and for its endlessly enumerable subvarieties. To take the latter problem first, consider a text from late in the process, the "Manual of Literature" compiled by an Imperial-era grammarian called Proclus. Proclus' discussion of lyric summarizes much from Didymus' On the Lyric Poets, which in turn drew on Alexandrian monographs on individual poets, themselves carrying forward studies of many of these same figures among the Peripatetics. By the early first century вСЕ a canon of nine (or ten) lyric poets had

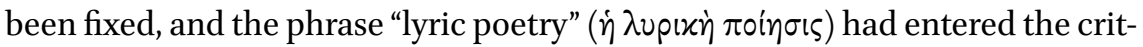
ical lexicon. ${ }^{2}$ The harvest of all this for Proclus was a complete system of poetic genres that identified lyric as a class of poems that, for all their variety, were distinct from epic, elegy, and iambus. Only after surveying these latter forms does Proclus take up "melic" poetry (the reason for his choice of term will emerge below) and remark: "Melic is the genre with the most subdivisions and distinct

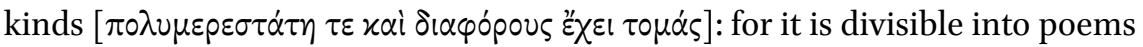
to gods, poems to men, poems to gods and men, and those for occasional events in life." ${ }^{3}$ Under these four subdivisions he compiles 28 lyric genres, though even these are not enough to capture the full variety of ancient lyric: Proclus leaves out a number of song names that are found in earlier authors, and other lists exist. ${ }^{4}$ The inadequacies of this scheme might suggest that lyric/melic is a catch-all category for "leftover" forms and so ancient lyric genres can safely be disregarded as unreal; but, as we will see, this vocabulary and its notional authority were a resource for poets as early as Homer, and some of these labels guided the production and reception of Greek poetry for a millennium.

For all its problems of definition, the question of genre imposes itself at a time when studies of Greek lyric are flourishing. To document this in the present volume would be superfluous, but it is worth highlighting how important notions of genre have been to the present revival. Beginning in the late

2 Färber 1936: 1-7. On Proclus: Severyns 1938; West 2013: 7-11.

3 Procl. ap. Phot. Bibl. 319b32-35 Bekker.

4 E.g. 24 lyric genres in the (mostly overlapping) Scholia Londinensia in Dionysii Thracis Artem Grammaticam 3.450.10-451.27 Hilgard. 
1970s, Claude Calame, Wolfgang Rösler, and Bruno Gentili moved beyond older notions of genre based solely on form and content and stressed the importance of the context of performance for defining kinds of poetry. ${ }^{5}$ This broader conception of genre tied to occasions of Greek social, political, and religious life remains central in many areas of research, such as Pindaric victory songs or the interactions between lyric and tragedy. ${ }^{6}$ It is also important, I will argue, to the current exploration of "chorality" as a modality that may migrate among several traditionally distinct lyric forms. As we investigate these aspects of lyric, it is crucial to avoid a one-dimensional attitude to genre lest, as often happens when we think in terms of "lyric," we fall into replicating memes from an outmoded Romantic theory and adopt its unhelpful dialectic between liberty and restraint, with genres playing the role of tyrannical impositions upon the spontaneous freedom of artists. ${ }^{7}$ This essay accordingly suggests some benefits for readers of Greek poetry in attending to ancient ways of classifying lyric song.

In what follows I will first put the problems of defining lyric genres in context by comparing recent debates in modern literary studies, where lyric has also been undergoing a contentious revival. While classicists have been concerned with relating specific lyric texts to performance situations, moderns have been looking at the problem from the other end and questioning whether these varied song practices constitute a coherent category of literature. In modern European literatures it is only late that an idea of "the lyric" comes onto the critical scene, and the grounds on which it does so are so dubious as to raise questions about whether it makes sense to speak of "the lyric" at all. These debates suggest that one promising way forward is to pay more attention to the historical processes by which ideas of lyric and its genres were constructed, moving the focus away from substantive definitions to the processes by which distinct kinds of nondramatic and nonnarrative song were identified and named. On this basis, I will then turn to the Greeks and outline their methods for lyric "generification" in the archaic and classical periods; generification is as old as song, or at least as old as the second song, and I will stress how it was the work of poets, audiences, and critics all together as they pursued not only taxonomic but ritual, pedagogic, communicative, and aesthetic aims. ${ }^{8}$

5 Calame 1977; Rösler 1980; Gentili 1984.

6 On Pindar, see most recently Morgan 2015: $1 \mathrm{ff}$. (on allegedly “impure" epinicia) and Maslov 2015: ch. 1, esp. 62-76. On tragedy and lyric, see Swift 2010; Gagné and Hopman 2013b; Andújar et al. 2018, as well as Foster's and Weiss' essays (this volume).

7 As in Croce's 1902 influential repudiation of genre. See Duff 2009 for a valuably complex picture of genre in Romantic theory.

8 As Leslie Kurke points out to me, Bell 1992 made a comparable move in replacing the term 
Surveying the parameters governing early lyric generification will show that the norms that prevailed in the period between Homer and Pindar were radically changed when Plato and Aristotle devised new literary systems based on what each called mimesis. The shift was momentous for, whether one translates mimesis as "imitating" or "representing," lyric poetry was marginalized in the new systems and as a result was never adequately incorporated into a synoptic scheme of literary forms with a special task of its own. At this point the ancient story joins up with the modern one, for the conception of poetry as mimesis developed in the classical period persisted through the eighteenth century and continued to determine the (non-)status of lyric. Here classicists have proposed a new way forward by defining a new notion of mimesis as neither "imitation" nor "representation" but "ritual reenactment." I will examine the merits and limitations of this suggestion and, in a final section, will take up one very old lyric form - the Linus-song - to argue that, despite the problems attaching to traditional Greek notions of genre, a sensitivity to lyric generification provides readers with valuable perspectives that neither mimetic nor ritual approaches afford.

\section{The Rise of Modern Lyric}

The arrival of the modern conception of lyric can be placed around 1800 when lyric was elevated into a full-fledged genre that could be set beside epic and drama as one of the three "natural forms," in Goethe's words, of serious literary production. ${ }^{9}$ Adumbrations of the idea can be found in eighteenth-century texts and earlier, but what most held lyric back from being recognized as a general class of literature was the orientation of classical theory toward mimesis, the "imitation" or "representation" of life and action. Mimesis in this sense had been, since Aristotle, the obvious function of epic or drama; some other kinds of poetry, such as satire or idyll, could also be said to "imitate" life as well, but a great deal of nonepic and nondramatic verse (e.g. sonnets, elegies, "Pindaric" and other odes) had very little in the way of plot or characters, making it unclear what such poetry "imitated." The 1800 turning point (whose arrival and causes are variously pinpointed by historians of criticism) was made possible by the

"ritual" with "ritualization" in order to grasp ritual as a form of social activity and so better to understand how such acts are differentiated from others and imbued with social value.

9 The account here draws especially on Abrams 1953; Guillén 1971; and Genette 1986; insightful shorter synopses: Patey 1993; Calame 1998a; Jackson and Prins 2014: 11-16; and the contributions of Goldhill and Güthenke in Billings et al. 2013. 
development in Romantic thought of a more robust conception of the inward, individual subject; this made it possible for lyric to be seen as mimetic, for it could be said to express the inner life of the poet, what Hegel called Erlebnis, "lived experience." Once lyric was endowed with mimetic content, it became eligible to be integrated among the classical genres and inscribed in a great dialectical history: an age of epic objectivity gave way to lyrical subjectivity in the seventh century вСЕ, followed by their synthesis in classical drama.

When lyric was elevated to the noble ranks of literature, it was assigned the expression of inward thought and feeling as its particular province, and this conception has proved hard to eradicate even as it has been steadily dismantled over the last half century. The New Critical pedagogy of the 196os was committed to an ideal of the autonomous work of art that reduced the lyric "I" to a persona, at best a fictional representation of any individual's real-life speech. René Wellek in a classic article of 1967 exposed the roots of lyric ideology in German Romanticism and challenged its overvaluation of expressiveness, which he thought threatened to engulf all other art in a single aesthetic project. Because any genre must be constantly transformed as it interacts with other genres, Wellek advised abandoning attempts to define "the lyric" and urged instead a focus on the variety of its narrower forms. ${ }^{10}$ Finally, scholars like Ralph Cohen and Jameson rejected essentialist approaches to literary form altogether and presented genres rather as social institutions, negotiable and self-interested. ${ }^{11}$ As a result, substantive definitions of lyric genres lost their normativity and were seen as open-ended processes, groupings of texts that were subject to repeated modification as new ends arose that needed to be fulfilled.

Still, one could argue for the utility of some general, if evolving, notion of lyric until Virginia Jackson led a "new lyric studies" movement in the past decade. ${ }^{12}$ These critics deplore what Jackson calls the "supersizing" of lyric in the nineteenth century as a distorting homogenization of diverse writing, performance, and publishing practices and one that now tyrannizes literary study. A specialist in Emily Dickinson attentive to the materiality of every scrap she jotted, Jackson protested against the editors and pedagogues who would hide the particularity of her work behind a screen of idealized "lyric." Quite apart from the injustice this perspective does to Dickinson, Jackson claimed, the collapsing of heterogeneous practices into a single reductive idea has had wider pernicious effects, leading to a current tendency among critics to "lyricize" their

\footnotetext{
$10 \quad$ Wellek 1967.

11 Cohen and White 2003; Jameson 1981.

12 Jackson 2005; cf. Yeager 2008 and the excellent anthology of lyric criticism by Jackson and Prins 2014.
} 
objects of study, in a term taken from Mary Poovey; this generalizing of lyric ideology to all literary expression, predicted by Wellek, can be seen in the common tendency now to equate "poetry" with lyric, a nearly complete reversal of the classical relegation of lyric to leftover status.

Most recently, Jonathan Culler has entered the fray with a book that in some respects pushes back against this trend. It is entitled Theory of the Lyric and its thesis is epitomized in the definite article: Culler argues that it is not enough to dissolve the category of lyric into an unassimilable variety of nonepic, nondramatic poetic practices, for to do so precludes any appreciation of how lyric poets create for themselves a larger tradition of their own. Acknowledging the need for critical attention to the historical processes that brought an idea of "the lyric" to the fore, he aims to revive the idea of lyric as a "set of norms and structural possibilities" that has "persisted since the days of Sappho, despite lyric's different social functions and manifestations." ${ }^{13}$ I think that current Greek lyric studies can profitably attend to both Jackson and Culler, accepting a process-theory of genre while also looking out for continuities that are maintained or reasserted in the transformations of lyric through history. As Culler argues, an overarching history of lyric need not blur the specificity of each poet and era but may in fact counteract the tendency of lyricization to reduce all poetic production to a single formula.

\section{The Rise of Archaic Lyric Genres}

The prevailing account of Greek lyric genres, again shrewdly epitomized by Most and Conte, is that in archaic Greece poetic kinds were defined and named partly in view of their form and content but primarily by "communally recognized, often ritually sanctioned situations of performance." But at a time that is usually located in the later fifth century and associated with the bookish Euripides, a fall occurred as such songs passed beyond their generative performative contexts and became the object of a more purely formal and aesthetic attention. Although this was a happy fall to the extent that it "facilitated artistic experimentation with genres," a vital link with social life was broken, and the subsequent rigidification and formalization of genres in Alexandria was a way of compensating for this lost significance. Heirs to Hellenistic poetics, we moderns misread early lyric texts if we ignore how their words related to the world and content ourselves with connecting words to words about words. Among

13 Culler 2015: 83-85. 
classicists' versions of this story is W.R. Johnson's nostalgic The Idea of Lyric, which holds up the ancients as a model of engaged, communitarian song that we have lost since Whitman. ${ }^{14}$

Such stories imply that a richer appreciation of genre in the archaic period may provide a path back to the bright, pre-fallen songworld, but the journey is not easy: to seek out some presumed essence of "the lyric" behind these texts would be to fall back into Romantic modernism, but neither can we take shelter in the historically attested, emic subgenres, for Harvey showed in a landmark article that their definitions usually go no further back than Hellenistic scholarship. ${ }^{15}$ Some light, however, may come from considering what I am calling lyric "generification" in the archaic and classical periods, observing both how certain forms of Greek song became recognized as distinct and nameable genres and how far this repertoire of nonepic, nondramatic songs was thought of as a coherent class.

A good enough place to begin is the representation of lyric in Homer. As expected, when he names kinds of nonepic song these are closely tied to specific sociopolitical occasions. Soldiers sing the paean when distressed or triumphant; matching male and female choruses sing the humenaios at weddings and the Linus-song at harvest; at funerals, female kin of the deceased dominate the dirge, threnos. These genres are socially defined not only by the occasions they accompany but by the way performing roles are assigned according to gender, status, and kinship. All this fits well with the idea of the social origins of Greek lyric genres, but it is crucial in using such evidence to keep in mind that Homer's agenda was something other than supplying us with raw ethnographic data. To see this it suffices to consider his description of the paean that the Greek soldiers perform in Iliad 1 to beg Apollo to stop the plague. After the delegation led by Odysseus has returned Chryseis to her father, the old man prays and sacrifices, there is a meal, and then kouroi serve wine to inaugurate a paean (1.469-474 West):

But when they had put aside the desire for food and drink, the youths crowned the wine-jars with drink and served out to all, first pouring drops for libation into the cups. All day they supplicated the god with song and dance, the young men of Achaea, finely singing the paean-song, singing and dancing for Hekaergos, and the god rejoiced as he listened.

\footnotetext{
14 Johnson 1982.

15 Harvey 1955.
} 


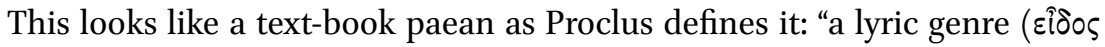
ఏंगेऽ) now addressed to all the gods but in ancient times addressed to Apollo and Artemis in order to stop plague and disease."16 The song name "paean," taken from its refrain, epitomizes its original function to invoke Apollo Paian as healer. Does Homer's scenario, then, prove that under the fussy Hellenistic classifications may lie real, ancient lyric forms that emerged from highly charged occasions of communal life? This may be, but a second look at the scene brings out elements that belong to paeans in a quite different spirit: this all-male group singing goes on for hours and comes after a meal as a separate service, marked off with libations; all this is more suggestive of the paeans that inaugurated archaic symposia, and indeed Homer's metaphor in saying the

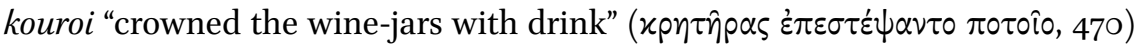
can evoke the garlands worn on such occasions. There is no doubt that occasion counted for much in early Greek conceptions of lyric, but already in Homer's time a single song-kind could be used on different occasions; moreover, if a poet's description of paeanic performance could take the liberty of mixing distinct uses of the form, we may suspect that actual musical arrangements could be flexible as well. ${ }^{17}$ The methodological upshot is that, in investigating early generification, we must not expect poets to be transparent reporters nor that we will be presented with the original, uncontaminated essence of songs.

If occasion was often the dominant factor in defining archaic lyric kinds, formal and thematic features were indispensable as well. The most basic and long-lasting formal distinction that Greeks made within what we call "poetry"

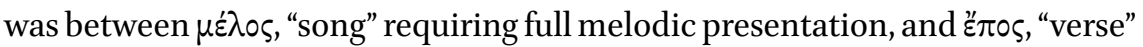
that may have been chanted but was not sung; as recitable verse, epos included hexameters, elegiacs, and iambo-trochaic stichoi, whereas Alcman's strophes or Sapphic stanzas counted as melos. Although general verbs meaning "to sing," such as i $\mu \nu \varepsilon i v$ and $\dot{\alpha} \varepsilon i \delta \varepsilon i v$, may be used equally of the performance of melos and epos, the key point is that melos is never used of songs composed in stichic form. (This is why Proclus uses "melic poetry" when he takes up lyric after treating epic, elegy, and iambus.) This formal distinction, rather than some assumed "expressive" function, is the strongest justification we have for continuing to speak of Greek lyric poetry, and it is the reason that Page's Poetae Melici Graeci and Lobel's collection of what he called the $\mu \dot{\varepsilon} \lambda \eta$ of Sappho and Alcaeus are in separate volumes from West's Iambi et Elegi Graeci. It should

16 Procl. ap. Phot. Bibl. 320a2O-24 Bekker.

17 Further on the paean in Il. 1: Ford 2006: 289-291; Wecowski 2014: 208-209. 
be noted, however, that the distinction between sung melos and recited epe was not purely formal for the Greeks, for each kind carried with it social implications, connoting, for example, certain skills, education, and experience required of potential performers and a range of roles available to audiences. Singable form was fundamental to lyric generification, but not as form for its own sake.

After occasion and form, the third and final parameter in defining archaic lyric kinds was "content," the range of topics conventionally thought appropriate to song in a given context and performative mode. Again, content was implicated in values beyond the literary, for the most basic and enduring distinction operating in this area was a religious hierarchy that segregated songs to gods from those for mortals. A well-known passage from the Homeric Hymn to Apollo can illustrate this (156-164):

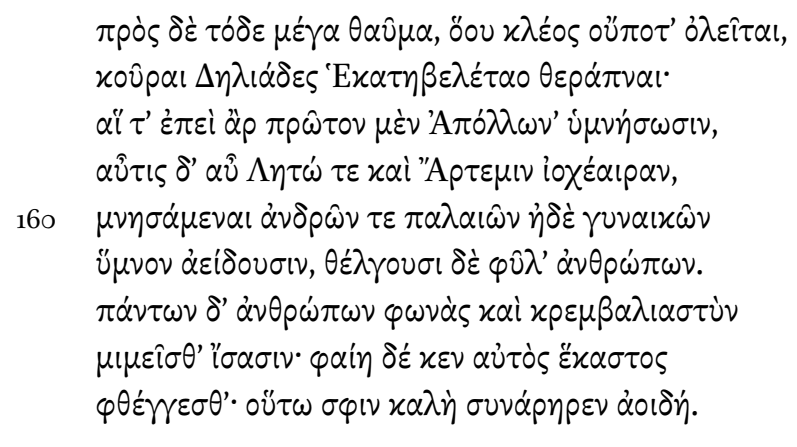

And there is this great wonder besides-and its renown shall never perish — the girls of Delos, handmaidens of the Far-shooter; for when they have first sung Apollo, and then Leto and Artemis who delights in arrows, they sing a song of men and women of the past, and enchant the tribes of men. And they know how to imitate the voices of all men and their clattering sounds: each would say that he himself were singing, so finely is their song fitted together.

This group of unmarried females favors certain themes that are clearly articulated and organized. First to be mentioned are their songs ${ }^{18}$ in honor of the island's patron Apollo: quite context-appropriate. Distinct from these ( $\alpha \hat{\tau} \tau\left\llcorner\varsigma \delta^{\prime}\right.$ $\alpha \hat{\imath}, 159)$ are songs for his virgin sister and mother: quite appropriate to the performers' gender and status. Only after these songs for the gods do we come to 
songs of early mortals in $160 .{ }^{19}$ The basic underlying distinction between songs for gods and songs of mortals underlies Proclus' primary division of lyric kinds quoted above and structures Plato's history of song in the Laws (70oa-e). Plato's speaker imagines that clear-cut generic distinctions prevailed in the musical

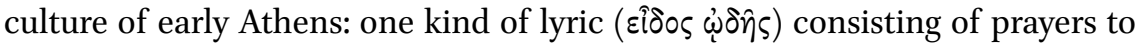
the gods was termed "hymns" and included paeans, dithyrambs, and kitharo-

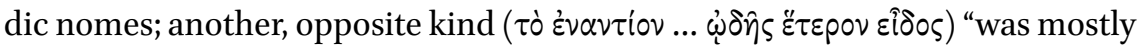
termed dirges." Plato's history goes on to include a fall in which poets began to mix these pristine forms, "blending dirges with hymns and paeans with dithyra-

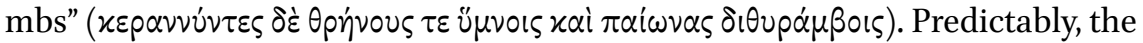
result of this neglect of "what is right and proper in the realm of the Muses"

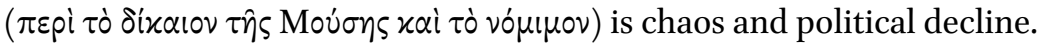

All three parameters are at work in a very rich story Pindar tells of lyric generification, a difficult fragment beginning a dirge: ${ }^{20}$

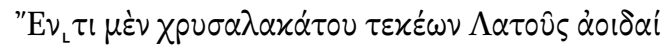

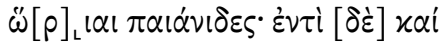

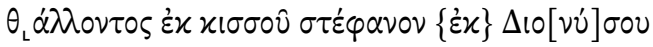

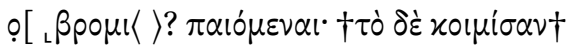

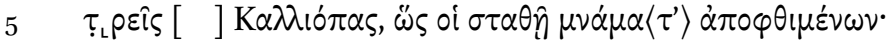

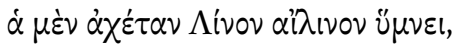

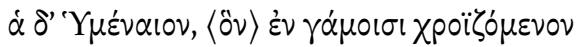

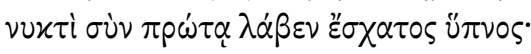

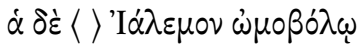

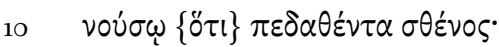

viòv Oiárpov $\langle\delta \dot{\varepsilon}\rangle$

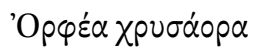

There are songs for children of Leto of the golden distaff, paeans in due season. There are other songs ... from flourishing ivy ... a garland of Dionysus

....

three ... of Calliope so there might be set up for her memorials of the dead:

19 Cf. Hes. Theog. 10o-101 where heroic song ( $\chi \lambda \varepsilon \hat{\imath} \alpha \pi \rho \circ \tau \varepsilon \rho \omega \nu \alpha \dot{\alpha} \theta \rho \omega \dot{\omega} \pi \omega \nu)$ is distinguished, hus-

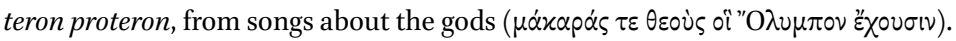

20 Pi. fr. 128c SM (= 56 Cannatà Fera $)$ with the text of Henry 1999 at vv. $6-8$. Cf. Calame 1998a: 101 for a different interpretation. 
one sang for clear-sounding Linus, ailinon; another for Hymenaeus, whom the last sleep took on that first night when his skin was touched in marriage; another for Ialemus when his strength was strapped by wasting disease; but the son of Oeagrus,

Orpheus of the golden sword ...

The opening four verses appear to distinguish paeans to Apollo and Artemis from Dionysus' dithyramb and then to set against these songs lamenting death in $5^{-10}$. Under the latter head Pindar collects three subvarieties which, as expected, show a similarity of form (refrain), theme, and occasion. Like Homer, Pindar is more than a simple reporter; he is actively synthesizing myths to provide an aetiology for each variety of threnos: Pindar makes Linus, Hymenaeus, and Ialemus children of the Muse Calliope, and suggests that upon each one's untimely demise his name was ceaselessly repeated in grief until the specific instance of mourning was transmogrified into a genre, a song-type that bore the name of its original object. (The importance of the refrain is doubly encoded

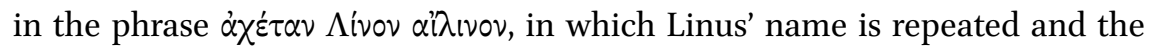
epithet underscores its sonic power.) The mention of Orpheus as the fragment breaks off is suggestive, since he was a singer who tried to cross the god-mortal divide, but the structure of the opening relies on the basic distinction made by Plato and Proclus between seasonally recurring songs to the gods and dirges, the quintessential expression of mortality.

Pindar's text bespeaks an age of anthropological interest in the varieties of song-types and singing practices before Herodotus and Plato. His testimony reveals that, well before Euripides came on the scene, the process of lyric generification itself might be a topic for a poet's conscious reflection and reimagination. The history implied by Pindar's syncrisis has a double message for classicists: on the one hand we are reassured to see that he uses the same three parameters to identify lyric genres as we do, but on the other it is worrying that his mythological scenario of how threnodic genres arose is the same as our "historical" model that traces lyric genres to the generalization of early cultic acts.

\section{The Rise of Classical Greek Lyric}

A fundamental change between archaic and classical taxonomy came when Plato and Aristotle, the granddaddies of the Greek genre system, downplayed 
the importance of social occasion in defining genres and replaced it with something each called mimesis. Mimesis, conventionally translated as "imitation," was given a different meaning by each author, but in both it denoted an enunciative mode of discourse, an immanent linguistic property. They thus removed the social determinants from archaic lyric genres and left the genre as a whole with only a formal definition. These well-known passages have momentous implications for the philosophers' views of poetry, but we will confine ourselves to observing how well lyric poetry fits into each one's system.

In the third book of the Republic (392c-394c), Socrates proposes that all of what we call literature ${ }^{21}$ falls into one of three basic kinds. This novel scheme (which may be Plato's invention) neglects performative context altogether and gives little importance to the formal melos/epos opposition; Plato's overriding consideration is the discourse's mode of enunciation. As Socrates explains $(394 \mathrm{~b}-\mathrm{c})$, there is one kind of poetry and tale-telling that consists entirely of "imitation" ( $\delta \dot{\alpha} \mu \mu \eta \dot{\eta} \sigma \varepsilon \omega \varsigma$ "ö $\lambda \eta)$, which he uses in Book 3 in the sense of impersonation; this is found in drama where everything is spoken in the persona of a character who is not the author. A second kind of literature works purely through narration ( $\left.\dot{\alpha} \pi \alpha \gamma \varepsilon \lambda \dot{ }{ }^{\prime} \alpha\right)$, with everything being delivered in the persona of the author/performer; this is exemplified by the dithyramb, a genre of lyric. Finally, there is the mode that mixes narration with the impersonation of characters, exemplified in Homeric epic.

Since the nineteenth century, this passage has been claimed as support for the tripartition of literature into drama, lyric, and epic. The importance of Gérard Genette's Architext is to have overthrown that claim, arguing that Plato's second class, pure narrative with no admixture of impersonation, hardly corresponds to our idea of lyric. He points out that, at the start of Plato's discussion

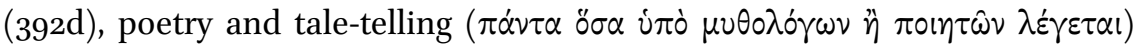

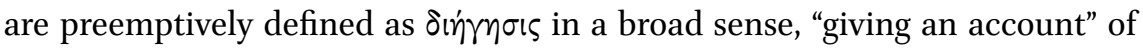
something. Thereby Plato leaves out of account all nonrepresentational poetry, including prayers, expressions of desire, enmity, or despondency —in short, he leaves out a good deal of what we would call lyric. To be sure, Socrates cites the dithyramb as an example of unmixed poetic narrative (394b-c), but his phrasing is curiously non-committal — the mode is "best exemplified, I sup-

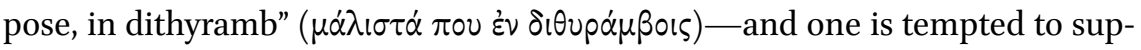
pose that this is because classical dithyramb neither always eschewed mimetic speech—Bacchylides' dithyrambs are a counterexample—nor seems always to

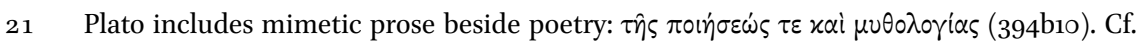
392d, quoted in the text below. 
have been bent on telling a story, to judge from Pindar's dithyrambs. However we work out that problem, ${ }^{22}$ the significant point is that Plato's definition of poetry as mimesis limits his recognition of lyric to those forms that were ostensibly narrative.

Aristotle's single most important difference from Republic 3 is to redefine mimesis as "representation" rather than "impersonation," but lyric will be as ill served in his scheme. ${ }^{23}$ The first three chapters of the Poetics set out a comprehensive grid on which one can locate all the major genres of poetry recognized in Aristotle's day (with a place for mimetic prose as well). Like Plato, Aristotle replaces occasion with mimetic mode, but he gives equal weight to form and content. Chapter 1 identifies literary forms according to how they combine three "media of representation": speech, rhythm, and melody; this entails a definition of lyric in formal terms as mimesis that uses all three media throughout (1447b24-26). (Epic, by contrast, never uses melos, and drama uses it only in the parts we call odes or arias.) The content or "objects of representation" discussed in chapter 2 are social/ethical rather than theological: people better, worse, or like us. It is in chapter 3 that Plato's modes are revised (1448a19-24):

The third difference in these arts has to do with the manner in which any one of these objects may be represented; for it is possible to represent the same objects in the same medium but in different modes. Thus they may be represented either in narration (whether the narrator speaks at times in an assumed role, which is Homer's way, or always in his own person without change) or in a mode in which the characters are presented as functioning and in action.

As the Hutton translation here reprinted makes clear, Aristotle turns Plato's tripartite classification of literature into a bipartite one: pure narrative and mixed narrative are lumped together into a single modal class that he opposes to dramatic mimesis/impersonation. The pure narrative class, the ostensible home for lyric in Plato's scheme, is folded in with epic and other mixed forms with the result that any distinctness lyric discourse may have is swallowed up.

Aristotle does not, as some charge, neglect lyric entirely, for we have seen it defined formally in chapter 1 where dithyramb and the kitharodic nome are its exemplars. Still, it is true that the Poetics as we have it pays scant attention to lyric forms except as an element in drama. To the extent that Aristotle's

22 Cf. Käppel 2000 for the view here, vs. D'Alessio 2013.

23 On mimesis in Plato and Aristotle see Halliwell 2002: 37-97. 
neglect of Pindar \& Co. needs an explanation, the most important cause lies in his commitment to mimesis. Different as their notions of mimesis are, Plato and Aristotle agree in defining poetry as mimesis in one enunciative mode or another; as a consequence, both have trouble taking account of the many kinds of lyric poetry that present no proper narratives but are rather rhetorical presentations of ethical points of view or expressions of conventional attitudes or emotive responses to situations; neither Plato nor Aristotle would think they "imitated" or "represented" anything much at all. ${ }^{24}$ It was this lack of an identifiable object of lyric mimesis that would keep the genre on the sidelines until 1800.

To sum up: in Greek literary history the musical form of lyric always singled it out as an empirically distinct class of poetry, but the various forms of song were not synthesized into anything like a super-genre in the classical age: Plato barely notices lyric in Republic 3, and Aristotle recognizes it mainly as a formal possibility in Poetics 1, while epic representation and dramatic impersonation claim his attention. There is force to Genette's argument that when modern critics found their tripartite scheme anticipated in Aristotle and Plato, this was merely a "retrospective fiction," an appeal to authority in hopes of naturalizing their own approach and thereby disguising, even from themselves, their innovative conception of lyric. What debarred Plato and Aristotle from bringing all lyrics together into a single substantive category, and what hid lyric so long from modern theory, was their assumption that poetry is mimesis, and so lyric theory must come to terms with that concept.

\section{New Notions of Mimesis}

The focus in Plato and Aristotle on poetry as mimesis, as verbal representations of characters in action, marginalized lyric in both classical and later European poetics, a marginalization that was only undone at the cost of reducing all lyric to self-expression. As we still stand in the shadow of that theory, it is good to be reminded by Earl Miner, the great scholar of comparative poetics, that Western criticism is an outlier in this regard: "Lyric," he says, "is the foundational genre for the poetics or systematic literary assumptions of cultures throughout the world" and the poetics it inspires are affective/expressive, not mimetic. ${ }^{25}$ Recent work on Greek lyric, however, has found a way to bypass the limitations

24 Menn (n.d.) is the best discussion I know of why Aristotle gives no extended account of lyric.

25 Miner 2000: 3-4, quoted by Culler 2015: 1. 
of the classical literary system by positing a new account of mimesis that does not depend on making expressiveness the essence of lyric and that reduces lyric taxonomy to a subsidiary problem.

The most influential theorist of the new model has been Gregory Nagy, who in a series of works has profoundly redescribed the turn from archaic to classical genre by redefining archaic mimesis. Nagy agrees with the usual account that occasion provided a necessary frame for early poetic speech acts, and he agrees that, when the performative occasion for a given kind of song was lost or felt to be lost, a sense of genre could compensate for that loss, even substitute for it in a way. But for Nagy a more important force shaping archaic poetry was mimesis, which originally meant neither Plato's mimicking of another nor Aristotle's representation of action in speech; Nagy's archaic mimesis was a ritual process by which a mythical origin was recaptured through the performer's impersonation in the sense of reenactment. A convenient illustration of Nagy's complex argument is the Hymn to Apollo above. Nagy points out that this portrayal of the Delian Maidens appears in a rhapsode's hexametric hymn, so that we have an intergeneric exchange: a rhapsode "imitates" a choir whom he will subsequently (166-173) bid to "imitate" his discourse in turn; for Nagy, the statement that the girls "know how to imitate" the voices of all people ( $\mu \mu \varepsilon i \sigma \theta$ ' " $\sigma \alpha \sigma \omega, 163)$ means more than copying local dialects or language: mimesis refers to the power of any chorus to reenact the founding performers of their song and to communicate that power to others who will reenact them in turn: as he puts it, "These Maidens are models of mimesis by practicing mimesis." ${ }^{26}$ So mimesis is a magico-ritual process in which "mimetors" are not belated "copiers" of earlier models, but reenactors of earlier reenactors on the same level. Pindar's threnodic fragment may be taken as an instance of mimesis in this sense, for he draws his new song into the genre of threnos by briefly reenacting the aboriginal divine refrains.

Nagy's focus on reenactment puts the putative origin of any lyric genre in brackets and indeed undercuts the usual account of how genres arise. On the usual account, genres arise out of real-life occasions that become generalized when repeated in other situations; a ritual-generated song, by dint of repetition in other, nonritual contexts, turns into art. But Nagy reverses this: ritual mimesis was never an imitation of "real-life" song events but itself generated the "original" event by conferring "absolute" status upon the putative model. The founding event is not to be sought in prehistory but stands before us as nothing more than the whole line of ritual reenactments of "absolute" models viewed

26 Nagy 1994-1995: 16; cf. id. 2013b and Peponi 2009 on the Hymn to Apollo. 
diachronically. Genre is thus a byproduct of ritual utterance; in fact it is a mirage created by a magical speech act that claims both to reproduce the speech act of a mythic model and to serve as a model for later occurrences of the song. ${ }^{27}$

Nagy's powerful account avoids the naiveté of seeking the essence of any genre in its putative original form; in addition, he warns that the determinative role accorded to "occasion" in the usual account may be a fantasy, a founding myth for the idea of genre. One must agree with Nagy to the extent that, whatever may have transpired in prehistory, we only have access to song genres as retrospective projections from later presents. One may still question, however, the historical shift posited in this model, for Nagy's history depends, like Pindar's, Plato's, and the "modern" theory of lyric, on a fall that has rendered a vital aspect of song in its original settings opaque to us. For Nagy, the great change was "caused by a gradual weakening of ritual practices" around the middle of the fifth century and is reflected in a contemporaneous shift in the semantics of the mimesis-words: ${ }^{28}$ when an originally secondary sense of "imitate" prevailed over an original primary sense of "ritually reenact," the work of poets as "reenacting" archetypal originals was forgotten and came to be replaced by the classical idea that poets "imitated" poets who had sung similar songs before. Ritual fell into art, poetry into technique, opening the path to Plato and Aristotle and their formal redescription of magico-ritual song as melos, whose power their belated mentalities could not properly appreciate.

This and allied conceptions of ritual mimesis influence many current studies of Greek lyric. In the shorter, "monodic" songs of Sappho and Alcaeus, for example, the speaking voice is increasingly seen not simply as a persona (far less as an historical personage) but as a traditional role, generic in the full sense of the term. Similarly, the overt occasionality of Pindaric epinician need not point to performance contexts but can be reabsorbed into the texts as a generic function of the praise-poet's role. ${ }^{29}$ So influential is this approach that ritual mimesis has become supersized itself and is now seen as the motor driving a wide range of archaic poetry. Much current work on Greek chorality endows that performative mode with a power that Albert Henrichs named "choral projection": a dramatic chorus can toggle back and forth between their occasion-defined role as performers in an Athenian Dionysiac festival and their mimetic role as

27 Cf. Barchiesi 2000: 174: "If one can assume that the original performance and its social context made genre superfluous, then genre, as Nagy has suggested, is a postmortem of performance."

28 Nagy 2013b: 228; cf. id. 1994: 15 .

29 See, e.g. Obbink 2014 on Sappho's recently found "Brothers" poems and Nagy 1994-1995 on Pindar. 
singers/actors in a heroic-age drama. ${ }^{30}$ More generally, something of the ritual idea of mimesis is invoked in Barbara Kowalzig's anthropological and sociological studies of chorality; for her, choral singing is not one performative mode among others but a "socially effective mechanism" for putting religious tradition to use. She is close to Nagy when she writes, "In choral performance ritual and art dissolve into each other: the difference between past and present is collapsed, as is the difference between the performing chorus and their mythical analogues." ${ }^{31}$

This line of approach to Greek lyric derives from structural anthropology and linguistics and regards poetry in the first instance as a species of human behavior and thence as a sublimated form of political and social activity. As such, it can bring out important operations of these works that a literary approach to genre would miss; but the reverse is also true, and I am not prepared to consign so much Greek lyric poetry to ritual: supersizing the idea of ritual mimesis and putting reenactment at the core of archaic lyric risks, in Genette's terms, stressing fiction over diction, gliding over what made each song unique and distinct, even from others composed for the same addressee on the same occasion. In addition, downplaying specific genres in favor of a generalized mimesis pervading all archaic song will overlook the ways that poets exploited traditional conceptions of lyric kinds to enrich their creations and invest them with authority. To illustrate, I conclude by tracing how one tiny archaic genre, the Linus-song, was generified from the pre-Hellenic Near East to Hellenistic Alexandria. It will be a story that does not rely on a fall, or at least one that puts the fall back before the story begins.

\section{Linus Generified}

The first remarkable feature of the Greek Linus-song is that its very name-and this epitomizes a key point I have argued - shows that it was already remade before it appears on our screens in ostensibly pristine form. In myth, Linus was an early-slain musical hero, the child of a Muse whose lamentation for her son gave rise, as Pindar suggests, to the Linus-song, a prototypical dirge. Philology takes the opposite view, interpreting the figure Linus as the personification of a

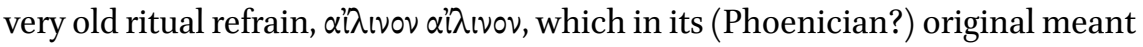
something like "Woe, woe is us." 32 A partially demythicized account is given by

30 See Gagné and Hopman 2013b.

$31 \quad$ Kowalzig 2007b: 67.

32 Chantraine 2009 s.v. $\lambda$ ivos, $L f r g E$ s.v. $\lambda$ ivov. On the Linus song: Färber 1936: 1.44, 71, 2.61ff.; 
Herodotus (2.79) who tells us that the song for Linus is performed in Phoenicia, Cyprus, and elsewhere under various names; he traces its origin to Egypt where the original name/refrain was Maneros. Egyptian informants persuaded Herodotus that Maneros was the son of their first king and that the lamentation that arose upon his early death was for a long time the only song in this ancient kingdom. ${ }^{33}$ Herodotus' generification begins (like Pindar's) by setting the Greek Linus-song beside other songs with comparable refrains in presumably similar tones. Like modern scholars (and unlike Pindar), he realizes that the Linus-song has an historical and not divine origin; for him, in fact, the name Linus is already a translation ( and his song is but a Greek derivative of a type to be found in other cultures.

Bearing in mind that the oldest kinds of Greek song we hear of have a backstory, let us turn to the earliest mentions of the Linus-song, first a fragment of Hesiod (fr. $305 \mathrm{M}-\mathrm{W}$ ):

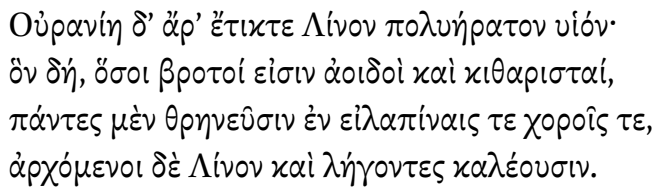

Urania then gave birth to Linus, her exceedingly lovely son, he whom all mortal singers and kithara players lament at their festive choruses, calling "Linus" as they begin and end.

The song is a variety of dirge invoking Linus, a Muse's offspring celebrated by those who play and sing to the kithara; all of them, Hesiod says, are wont to call on Linus "as they begin and end." Taking Hesiod as a reporter would suggest that such performances in his day regularly featured the refrain $\alpha^{i} \lambda$ ivov $\alpha^{i} \lambda \iota v o v$; the mention of choruses suggests a call-and-response performative mode. We thus picture the Linus-song as an antiphonal lament for a figure that kitharasingers portrayed as the patron of their art.

We hear more about the song in Homer: when Hephaestus represents a city at peace on Achilles' shield in Iliad 18, he decorates it with two songs, a wedding song (491-497) and the Linus-song. The latter accompanies a grape harvest $(565-572)$ :

Häussler 1974; Calame 1977: 1.154-155 with bibliography at n. 217; on Linus: West 1983: 5667; Stephens 2002-2003; Power 2010: 208-210 (with nn. 55, 58), 212. 


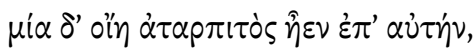

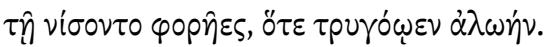

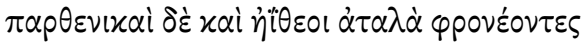

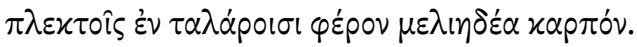

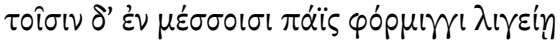

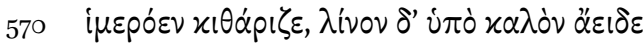

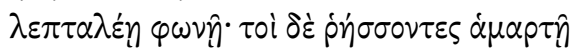
$\mu \circ \lambda \pi \hat{\eta} \tau^{\prime}$ i

And one single path led thereto [the vineyard], which the vintagers took whenever they gathered the vintage. And maidens and youths in childish glee were bearing the honey-sweet fruit in wicker baskets. And in their midst a boy played the kithara delightfully on a clear-toned lyre, and sang beautifully in accompaniment the Linus-song with his delicate voice; and his fellows beating the earth in unison followed on with bounding feet dancing and shouting.

Formally, this looks like a rustic version of Hesiod's Linus-song: paired choruses of unmarried boys and girls carry fruit in baskets and frisk about a boy who plays a lyre; as he sings, the choristers dance and "shout out," very probably its ritual refrain ( $i v \gamma \mu \hat{\omega}, 572$, is an onomatopoeic word).

If we press further and ask what the boy sings, grammar leaves room for interpretation: my translation follows most modern commentators in taking it that the boy "sang in accompaniment to ... his clear sounding lyre" ( $\varphi$ ópuir/

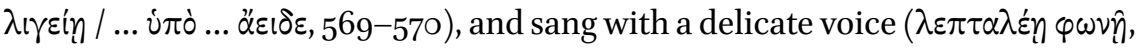
571). ${ }^{34}$ As for what he sings, reading a proper name in 570 and translating $\Lambda$ ivov

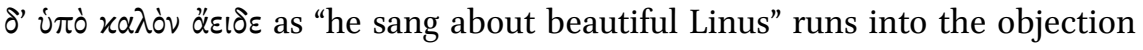
that the verb $\alpha \dot{\alpha} \delta \delta \varepsilon i v$ in epic does not normally take a personal object: when $\alpha \dot{\varepsilon}-$ $\delta \varepsilon \imath \nu$ governs an accusative this will be the name of a song-type (such as paean, Il. 1.174) or an abstract statement of theme (such as "Achilles' wrath," Il. 1.1). ${ }^{35}$ Hence most read $\lambda$ ivov as the name of a lyric genre: "he sang the Linus-song beautifully."36 This reading is entirely plausible, for we have already seen in the case of the paean that by Homer's day proper names of patron figures had been generalized into names of the songs honoring them.

On this reading, Homer testifies to the importance of occasionality in the archaic genre system by embedding the Linus-song in a context. Mark Edwards,

34 So Leaf 1902 ad 18.570; Edwards 1991 ad 18.569-570.

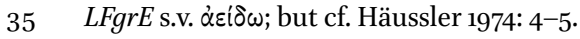

36 With $x \alpha \lambda$ óv adverbial: Diehl 1940: 106; Häussler 1974: 3 n. 9. 
however, comments: "The [Linus] song is always referred to as a dirge, and it seems odd to sing it here on what is obviously a cheerful occasion" (1991: 225). An explanation is not far to seek: a dirge to accompany vintaging makes perfect sense ethnologically, for Linus belongs, like the early-dying Adonis, to Easternstyle fertility cults featuring songs of lamentation at harvest. ${ }^{37} \mathrm{Hence}$, presumably, Hesiod is untroubled by the idea of a festive song lamenting Linus ( $\theta p \eta$ -

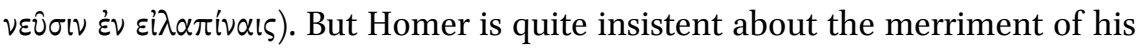

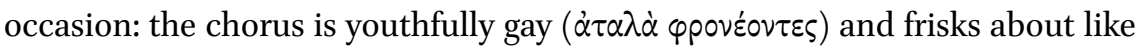

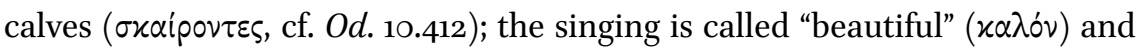

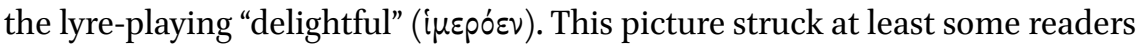
as anomalous and may be the reason that Zenodotus suggested a different construal of the text. A scholiast informs us that Zenodotus proposed to read not $\lambda i v o v$ or $\Lambda$ ivov in the accusative, but $\lambda$ ivos, which he apparently took as an alternate nominative form of the word $\lambda$ ivov, -ov, "flax-string": "the boy played the lyre delightfully, and the flax-string sang beautifully in accompaniment to his delicate voice" (570-571). The scholiast filters Zenodotus to us through his critic Aristarchus, so we cannot be sure of his intentions, but other ancient commentators raise the possibility that he meant to restore consistency of occasion to the Linus-song by emending away this incongruously cheerful example: on his reading, Homer says nothing about a Linus-song but only mentions a singing string. Zenodotus could have pointed to a good Homeric parallel for the syntax: when Odysseus strings his bow in the Odyssey and tests it by plucking the

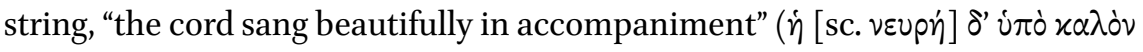

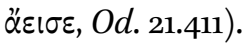

But the great Aristarchus would have none of this, as the same scholiast informs us: he took $\lambda$ ivov as the accusative of $\lambda$ ivos, which he explained was the name of a song genre ( $\gamma \varepsilon \dot{\varepsilon} v \varsigma \tau \iota$ ü $\mu \nu 0 v)$; Homer's phrase "is the equivalent of saying 'the boy sang a paean' or some such genre."38 As I said, modern commentators side with Aristarchus, but Zenodotus' "string theory" had earlier supporters. One was the cultural historian Philochorus of Athens in the third century ВСЕ. He related a myth in which Linus was killed by Apollo because he replaced his kithara's flax-string ( $\lambda$ ivov $x \alpha \tau \alpha \lambda \nu$ v $\sigma \alpha \varsigma$ ) with gut-strings $(\chi 0 p \delta \alpha i \varsigma){ }^{39}$ Thus an old story of pastoral-agricultural antagonism provided an alternative aetiology for the Linus-song, deriving its name not from the slain hero but from

37 Shaw 2013: 184-191. Sappho 214 Voigt (= 140b LP) associated Linus (under the name Oitolinus) with Adonis.

38 Schol.(A) ad 18.570a. Zenodotus' suggestion is called "not indefensible" by Leaf 19o2: 2.311312 ( $a d$ 18.570) and is defended by Van der Valk 1963: 1.153-154 and Barris 2016.

Philoch. FGrHist 328 fr. 207 (= Schol. Il. 18.570c3 ff.). 
the instrument of his devotees (in its imagined earliest form). Earlier still, Heraclides of Pontus noticed this passage and commented that, though Homer was aware of gut-strung lyres, he kept the word $\lambda$ ivov. ${ }^{40}$ I suggest, then, that for some exegetes the Linus scene raised worries about the consistency of occasion in an old lyric genre, and this worry is explicit in the Attic Glossary of Aristophanes of Byzantium. Listing a series of folk genres, Aristophanes says the himaios was a miller's song, the humenaios went with weddings, and ialemos with occasions of mourning; "but linos and ailinos are sung not merely on occasions of mourning but also 'upon a happy song,' as Euripides has it [in Heracles 348]."41 Aristophanes seems to have agreed with Aristarchus and modern commentators in recognizing a Linus-song in Iliad 18, but, like Edwards, he realized he was admitting a usage that fit ill with other data about the genre.

On the usual account of archaic generification, the name of the Linus-song preserves its organic connection to a social occasion of pre-Homeric antiquity; and as that connection faded, some later scholars explained the song's name from the instrument still used in such celebrations. Nagy rightly cautions that the alleged origin may be a mythic projection from the present, though the persistence of $\lambda$ ivov, a non-Indo-European word, as a name for vegetable fabrics today inclines me to keep the historical scenario alive as a possibility. I would, however, add a complicating suggestion: the string-etymology need not be regarded as the fruit of a post-archaic, "fallen" phase in the generification of the Linus-song, for it is animadverted to in Homer's text itself. Like Pindar, Homer may have been less concerned to document archaic song customs than to enter into ongoing negotiations about the contexts and history of a form. The Linus-song was, after all, already old and exotic for Homer and may have been more talked about than actually heard, since not enough examples survived to find their way into Proclus' handbook. Homer seems aware of the antiquity of the song, inscribing it, along with the humenaios, on a divine artifact made while the Trojan War was still in progress; he also seems aware of the type's ethnographic affinities in placing it at a harvest festival. But with the phrase $\lambda \varepsilon \pi \tau \alpha \lambda \varepsilon_{n} \varphi \omega \nu \eta \hat{~ i n ~ 18.571 ~ H o m e r ' s ~ t e x t ~ a l s o ~ g e s t u r e s ~ t o w a r d ~ t h e ~ a l t e r n a t e ~ r e a d i n g ~}$ that would silence the Linus-song while making the lyre-string sing. The epithet, an extended form of $\lambda \varepsilon \pi \tau o ́ s$, is a hapax in Homer and slightly oddly used, as Edwards also notes (on 18.571-572): "The meaning here is not obvious, but presumably complimentary."42 Literally "peeled" or "husked" (Il. 20.497), $\lambda \varepsilon \pi \tau o ́ \varsigma$

\footnotetext{
$40 \quad$ Heraclid. Pont. 16o Wehrli (= Phot. Lex. s.v. $\lambda$ ivov).

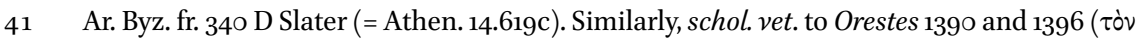

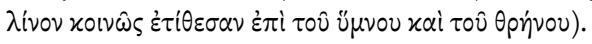


could be extended to mean "thin" in connection with voice, but a thin voice seems hardly wanted for an outdoor festive song, so the word is usually further extended to mean "fine" or "delicate" with the implication of "pleasing," as the

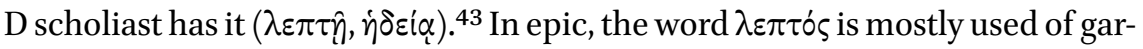
ments and other woven fabrics. Indeed, the Iliad applies $\lambda \varepsilon \pi \tau$ ós to $\lambda$ ivov in 9.661

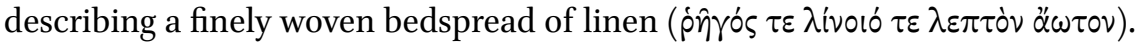
So the boy in Iliad 18 may well be, as Aristarchus held, singing the Linus-song, but with a voice that is fine-spun as a linen thread. ${ }^{44}$ Supported by the syntactic parallel from Odyssey 21, $\lambda \varepsilon \pi \tau \alpha \lambda \varepsilon \dot{n} \eta \omega \omega \eta \hat{\eta}$ leaves us uncertain whether the lovely Linus-song derives from a kithara string or from a dying god. ${ }^{45}$ Homer's epithet $\lambda \varepsilon \pi \tau \alpha \lambda \varepsilon_{n}$, then, suggests an aetiology to explain why, as Hesiod attests, Linus was a patron of kithara players; but at the same time, by occluding Linus, it could transport us to a pre-Iliadic songworld in which the proper name had yet to be generated.

This look at the archaic Linus-song suggests that the histories we tell about the generification of lyric can go back well beyond our earliest texts and so may not be fully captured in a "before and after" scenario. We are accustomed to think that a devotion to poetry that was $\lambda \varepsilon \pi \tau$ ó in the sense of "subtle" marked the new aesthetic of Callimachus and his Roman heirs (whose tenuis glosses $\lambda \varepsilon \pi \tau \dot{s} \varsigma$ ), though we must also allow that antecedents for this use of the word are already found in Attic comedy. ${ }^{46}$ But the $\lambda \varepsilon \pi \tau \alpha \lambda \varepsilon \dot{\eta} \eta$ voice of the Linus-song encourages us at least to lengthen this history and perhaps too not to seek a turning point at which early communal genres "fell" to become belated abstractions. It was already impossible for Homer to speak about any kind of song without being also an ethnographer of song, for the choice to represent a harvest- or a wedding-song required a name under which to locate it, an address in the social imaginaire where old, nonepic song was to be found. For reasons we can only guess at, the Iliad poet declined to take the opportunity his ecphrasis afforded to depict an early epic poet singing epic, though the Odyssey frequently indulges in such self-regarding ironies. On Hephaestus' shield, Homer apparently wanted to represent song sub specie aeternitatis, and in casting about for an old song the activity of harvesting, like marrying, was a

\footnotetext{
43 Cf. Chantraine 2009 s.v. $\lambda \dot{\varepsilon} \pi \omega$.

44 Diehl 1940: 89 would go further and connect $\lambda$ ivo $s$ with metaphors for singing as "weaving"

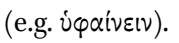

45 For wordplay with traditional refrains, cf. Pind. fr. 128c.6, $7-8$ above: $\Lambda$ ívov $\alpha i \lambda$ เ

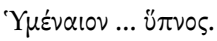

46 E.g., Ar. Ran. 828, 876, 956, Nub. 153, 320, 1496 with O'Sullivan 1992: 137-138, 142. On Linus as a figure of leptotes in Alexandrian poetics, see Stephens 2002-2003.
} 
good place to look. It is not at all surprising, then, to find Homer not only evoking lyric genres but participating in their ongoing redefinition. We do not have to wait for the iconoclastic Euripides to find the productive power of poetic genres reflecting on genre. Indeed, it seems that precisely because these were Homer's issues, Euripides was provoked to step in and reexamine Linus' genre in his Heracles.

In arguing that the Linus-song was not confined to occasions of lament, Aristophanes of Byzantium cited as an example the extraordinary first stasimon of that play, which begins by declaring itself a generic hybrid ( $H F$ 348358):

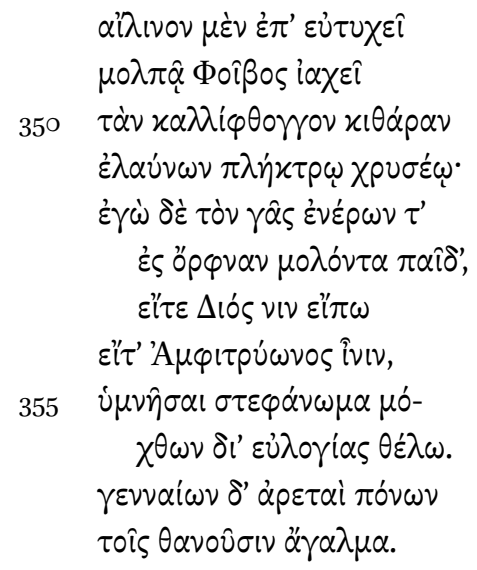

Ailinon cries out Phoebus upon a happy song, striking his fair-sounding lyre with a plectrum of gold; but for that one who has entered the darkness of the earth and of the dead - whether I am to call him child of Zeus or of Amphitryon-I wish to sing a song of praise as a crown on his labors: the noble struggles of the good are their delight when they die.

Although they have heard that Heracles is dead, the old men of Thebes announce that they will sing a congratulatory song, "crowning his labors with praise" (355-356), and the long decorative ode that follows celebrates his triumphs when one would have expected a dirge. ${ }^{47}$ An excuse for this mismatch of song to occasion is the fact that one may doubt, as the singer does, whether the deceased is to be praised as a mortal or as semidivine (352-355); the age-old

47 On epinician elements in this ostensible dirge, see Swift 2010: 121-129. Weiss' essay (this volume) brings out the "polyphony" and generic "malleability" of the other lyrics in this play. 
shibboleth expressed in Proclus, Plato, and earlier does not work here. But like a good mimetic choir, the chorus can take Phoebus as their model, who mixes messages when he "cries out ailinon upon a happy song" (348-349).

As a matter of literary history, it is not clear what Euripides might be referring to here: Fränkel assumed certain Apolline songs must have used the ailinon refrain; but it may simply be, as Bond suggested, that Phoebus stands metonymically for the kithara music he inspires and that ailinon was relatively common as an ephumnion in that repertoire (or was thought to have been so once, with Hesiod fr. $305 \mathrm{M}-\mathrm{W}$ in mind). ${ }^{48}$ Whatever practices the chorus is claiming as precedent, it would be too simple to sum up the Heracles stasimon as a characteristically "modern" mixing of pure genres. Euripides does indeed produce a lyric not quite like any that has come before, but his crossing dirge with epinician is not arbitrary defiance of generic convention but a desperate engagement with the limits of those conventions: facing the unprecedented challenge of singing a god-man, he reaches back to the roots of lyric to claim as precedent the Linus-song's notorious instability between mourning and celebration.

My aim has been to defend the relevance of genre-aware criticism to Greek lyric not simply by pointing out that even travesties of genre depend on genre, nor by reiterating what everyone allows in theory-that generic "constraints" can be productive and are in any case always at work. I began by acknowledging that classical and classically derived conceptualizations of lyric genre are not directly useful in exploring how lyric poets worked with genre because of their attachment to notions of poetry as mimesis. I then argued that we can compensate for these limitations to an extent by turning away from genres as literary essences and attending instead to generification, to representations in Greek lyric of how song genres arise, claim authority, and are modified. But I also submit that we need not go further and construct from such representations a history of lyric generification as a story of fall from an original fullness of meaning, a story that in itself must incur suspicion as a Romantic trope. As Nagy's analysis suggests, the usual fall story is less valuable as history than as a poetic move in the texts themselves, hinting to audiences that, amid the endless variety and confusion of speech, the primordial form of this song is about to reappear and to exert its ritual power. But by the same token Nagy's own fall story from ritual to romance must also be regarded as an effect of the text. A look at the Linus-song suggests that poets early learned to revise and exploit 
lyric history not because they had fallen out of touch with an organic song community but as a way of complicating the response of an audience who wanted the new song to work like the old: the tactic of invoking an unspoiled version of the present song in the past is a risky one that may seem to concede that the dream of unfallen speech has already been confounded by history and that no lyric now can be quite perfect nor completely efficacious. But this gambit can also be a way of suggesting that, in the messy congeries of the present, that same old song may be rising once again on this occasion in this season.

Lyric genres do rise and fall in history-Who sings the Linus-song now?but they are not mere phantoms from the past. If we attend to the work done by traditional genres in our texts, pausing to grant them some power before dissolving them into other genres or rushing past them as of no consequence to true poets, we will be able to notice how lyrics may reenact both the original state and its fall concurrently. Generification arises as a topic of song in many Greek lyrics because any occasion that calls for song calls for the (re)establishment of a form in which to sing with authority. Thus to pause any history of lyric on the fall is to give an incomplete account. To read ancient lyrics in ancient terms is to be open to the possibility that old genres can come to life again, like Linus, and to recognize that even in their late, revised, and reconstituted forms they are not cut off from the wellsprings of lyric. 